I am inclined to think that after their first moult the young crayfish feed, beneath the tail of their mother, upon the pellicles of the eggs and the earapace thrown off in this first moult; but I am waiting for further observations before asserting this positively.-Comptes Rendus, July 4, 1870, tome 1xxi. pp. 42-45.

\title{
The Brachiopoda a Division of Annelida.
} By Edward S. Morse.

At a meeting of the Boston Soeiety of Natural History, June 1st, 1870 , Mr. Edward S. Morse made a verbal communication on the position of the Brachiopoda in the animal kingdom. He referred to the branch of Mollusca as it was understood forty years ago, when, misled by external eharacters, many worms, like Serpula and Spirorbis, and a group of erustaceans, the Cirripedia, were included with mollusks, and remarked that, from a proper recognition of their charaeters, these diverse forms had been eliminated from time to time, and referred to their proper branches. After long and careful study, Mr. Morse was prepared to state that the Brachiopods were true Articulates, and not Mollusks, and that their proper place was among the worms, forming a group near the tubicolous Annelids.

He stated that for the past year he had been deeply engaged in the study of the Brachiopoda, and more particularly their early stages. Besides material from the coast of New England, he had had, through the kindness of Prof. A. E. Verrill, a large lot of Discina from Callao, Peru, belonging to the Yale College Museum. From these he had studied their early stages; but as he had in preparation a memoir upon the subject, he would now confine himself to the considerations that follow.

He first spoke of the structure and eomposition of the Brachiopod shell, and pointed out the relations between the ercal prolongations of the mantle in Terebratula and a similar structure in the test of Crustacea. He had also noticed a marked resemblance between the polygonal cells in the shell of a young Discina and a similar feature in certain lower crustaceans. The scale-like structure of the test of Idotoea resembled the scale-like strueture in Lingula. The skin of Nereis had similar punctures or dots, as seen in Terebratula and also in the peduncle of Lingula. He had submitted the shell of Discina to chemical tests, and believed it to be chitinous. Gratiolet had already given the chemieal analysis of Lingula anatina, and found forty-two per cent. of phosphate of lime, and only six per cent. of carbonate of lime. The position of the valves of all Brachiopoda were dorsal and ventral; and this was a strong artioulate character, to be compared to the dorsal and ventral plates of the Articulates. The horny setæ that fringe the mantle of Brachiopods was a feature entirely absent in the Mollusea, and peeuliar to the worms.

The bristles of worms differ from those of other articulate animals in having sheaths containing muscular fibre, while in other Articulates the hairs were simply tubular prolongations of the epidermal 
layer. In Brachiopods the setæ or bristles were secreted by follicles imbedded in or surrounded by muscular fibres, and were moved freely by the animal. In the structure of the setæ he found an identity with that of the worms. He then called attention to the resemblance between the lophophore of the Erachiopods and a similar structure in the tubicolous worms. In Sibella the cephalic collar was split laterally, and a portion of it reflected. Let this collar be developed so as to cover the fringed arms, and a representation of the mantle of Brachiopoda would be attained. The thin and mnscular visceral walls suggest similar parts in the worms. The circulating system he had not sufficiently studied, though Dr. Gratiolet had stated that in this respect there was a strong resemblance to the Crustacea.

In regard to the respiratory system, Burmeister had shown that there was a resemblance between the soft folds or lamellæ developed on the internal surface of the mantle of Balanidae and similar features in Lingula; though the existence of these folds in Lingu'a had been questioned, he would presently show that Vogt was right in his observations. In regard to the reproductive system, he called attention to the fact that in one group of Cirripeds the ovaries were lodged in the upper surface of the peduncle, while in another group the same parts were lodged in the mantle. A similar condition existed in the Brachiopods, where in one group the mantle holds the ovaries, while in another group they are found in the visceral carity.

Through Polyzoa, also, he showed that, in their winter eggs or statoblasts, a relation was seen to the ephippia of Duphnice, and the winter eggs of Rotifers.

Of great importance also, and upon which he laid particular weight, were the peculiar oviducts with their trumpet-shaped openings, so unlike the oviducts of mollusks, and, as he believed, bearing the closest affinity to the oviducts in many of the worms,- namely, a pair of tubes, and in one case two pairs, having their inner apertures with flaring mouths, suspended in the visceral cavity, thus opening a direct communication between the visceral fluids and the surrounding media. He then called attention to what little information we had regarding the embryology of the Brachiopods. LacazeDuthiers had shown that in Thecidium the embryo was composed of four segments with eye-spots and other strong Articulate features. Fritz Müller had given a description, with figures, of the early stage of Discina, in which we have not only little cirri projecting from the shell, but a little appendage recalling the plug or operculum in some of the tubiculous worms.

Ot great importance, also, was the fact that in the early stage of Discina, Müller observed large bristles, and these were moved freely by the animal. Smitt had shown that in certain Polyzoa (Lepralia) the embryo, besides being furnished with cilia, also supported several bristles or setæ, which were locomotive; and, finally, in the worms, Claparède and Mecznikow had figured an embryo of Nerine in which barbed bristles were also developed. Mr.Morse referred to his communication before the American Association for the Adrancement of 
Science on the early stages of the Brachiopods, in which he had shown the intimate connexions existing between this group and the Polyzoa. Now Leuckart had already seen reasons for placing the Polyzoa with the Annelids; and he would call attention to Crepina gracilis and Phoronis hippocrepia (admitted to be worms, or early stages of them), and their close resemblance in nearly every point of their structure to the hippocrepian Polyzoa. Mr. Morse then stated that in the evidence already given he had drawn his conclusions from alcoholic specimens of Terebratula and Disina, and from the papers of Lacaze-Duthiers, Claparède, Mecznikow, Hancock, Huxley, Vogt, Hyatt, Williams, De Morgan, and others. He felt the importance of first examining Lingula in a living condition before making these announcements; and for this reason he had recently visited the coast of North Carolina for the express purpose of finding, if possible, the rare Lingula pyramidata of Stimpson, first discovered by Prof. Agassiz in South Carolina. After nearly a week's fruitless search, he had found it, had studied it alive, and had brought with him living examples, which he had the pleasure of exhibiting before the Society.

He would here express his deep sense of gratitude to Dr. Elliott Coues, Surgeon U.S.A. at Fort Macon, N.C., and to the Commandant of the Post, Major Joseph Stewart, U.S.A., for the constant aid and sympathy rendered to Dr. A. S. Packard and himself during their visit there. He would not enter into a description of Lingula, as he had already in preparation a memoir upon the subject, but would call attention simply to the additional evidence in support of the views advanced.

Lingula was found in a sand-shoal at low-water mark, buried just below the surface of the sand. The peduncle was six times the length of the shell, and was encased in a sand-tube differing in no respect from the sand-tubes of neighbouring Annelids. In many instances the peduncle was broken in sifting them from the sand, yet the wound was quickly repaired, and another sand-case was formed.
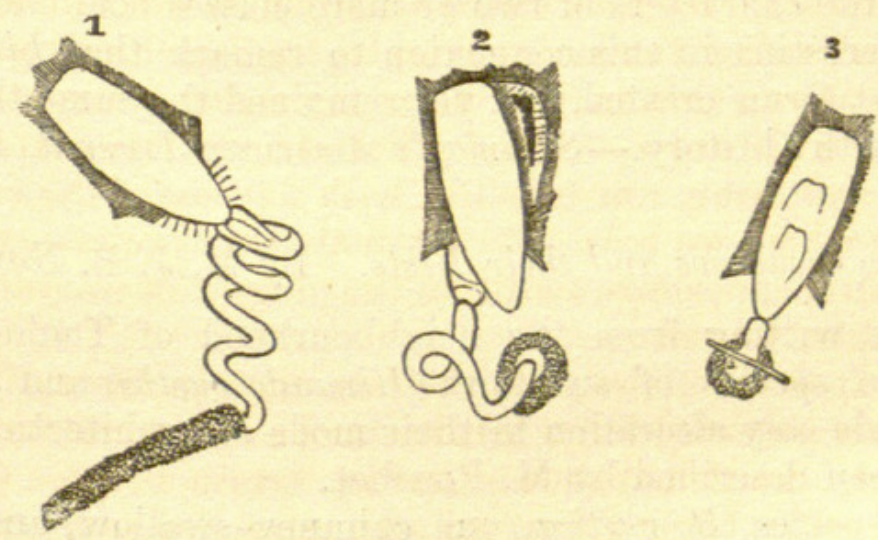

Fig. 1. Peduncle perfect, retaining portion of sand-tube.

Fig. 2. Showing valves in motion; peduncle broken and forming new sand-case.

Fig. 3. Peduncle broken close to the body, and forming new sand-case. 
He observed that Lingula had the power of moving over the sand by the sliding motion of the two valves, using at the same time the fringes of setæ, which swung promptly back and forth like a galley of oars, leaving a peculiar track in the sand. In the motion of the setæ he noticed the impulse eommencing from behind and running forward.

Within the mantle he found a series of rows of prominent lamellæ in whieh the blood rapidly cireulated-thus eonfirming the correctness of Vogt's observations. These lamellæ, however, were contractile.

The peduncle was hollow, and the blood could be seen coursing baek and forth in its channel. It was distinctly and regularly constrieted or ringed, and presented a remarkably worm-like appearance; it had layers of cireular and longitudinal muscular fibre, and coiled itself in numerous folds, or unwound at full length; it was contractile also, and would quiekly jerk the body beneath the sand. But the most startling observation in connexion with this interesting animal was the faet that its blood was red. This was strongly marked in the gills and various ramifications of the mantle, and in the peduncle. At times the pedunele would become congested; and then a deep rose blush was markedly distinct. Mr. Morse expressed his gratifieation in having come to the conclusions in regard to the annelidan eharacters of Brachiopods a long time previous to his observations on Lingula.

He then coneluded by stating that the Brachiopods, with the Polyzoa, should be removed from the Mollusea, and placed with the Articulates among the Annelids; that the Brachiopods eame near the tubiculous worms, though they were mueh more highly cephalized; that they exhibit certain Crustacean characters, but were widely removed from the Mollusea, unless a relation could be traced through the homologues of the Polyzoa to that aherrant group, the Tnnicates, as pointed out by Allman. He believed the Brachiopods to be a comprehensive type, exhibiting general Articulate features, and forming another example of those groups belonging to the last that exhibit the characters of two or more classes combined.

It was interesting in this connexion to remark that Lingula, one of the earliest forms created, had yet remained the same through all ages of the earth's history.-Silliman's American Journal, July 1870.

\section{Our two Swallows and their Nests. By M. J. B. Noulet.}

M. Noulet, writing from the neighbourhood of Toulouse, states that the two species of swallows (Hirundo rustica and $H$. urbica) have not made any alteration in their mode of architecture such as has lately been described by M. Pouchet.

The first species, $H$. rustica, our chimney-swallow, and the $\mathrm{Hi}^{-}$ roundélo of Languedoe, builds a nest which is broadly open like a balcony in all its free part; and the young birds which occupy it show their heads all round the opening, especially when expeeting the return of their parents. The nest of $H$. urbica, on the contrary, 


\section{$2 \mathrm{BHL}$ Biodiversity Heritage Library}

Morse, Edward S. 1870. "The Brachiopoda a division of Annelida." The Annals and magazine of natural history; zoology, botany, and geology 6, 267-270. https://doi.org/10.1080/00222937008696246.

View This Item Online: https://www.biodiversitylibrary.org/item/93156

DOI: https://doi.org/10.1080/00222937008696246

Permalink: https://www.biodiversitylibrary.org/partpdf/67987.

\section{Holding Institution}

Missouri Botanical Garden, Peter H. Raven Library

\section{Sponsored by}

Missouri Botanical Garden

\section{Copyright \& Reuse}

Copyright Status: Public domain. The BHL considers that this work is no longer under copyright protection.

This document was created from content at the Biodiversity Heritage Library, the world's largest open access digital library for biodiversity literature and archives. Visit BHL at https://www.biodiversitylibrary.org. 